\title{
УOBOЗНАВCTBO. ПUTEDATУРOЗНАВCTBO
}

\author{
УДК 811.111.4'25
}

DOI https://doi.org/10.24919/2308-4863/37-3-15

\author{
Катерина ПОДСЕВАК, \\ orcid.org/0000-0002-2114-4471 \\ кандидат філологічних наук, \\ старший викладач кафедри англійської і німецької філологї \\ та перекладу імені професора I. В. Коруния \\ Київського начіонального лінгвістичного університету \\ (Київ, Україна) kateryna.podsievak@gmail.com
}

\begin{abstract}
Наталя БІЛОУС, orcid.org/0000-0002-6416-0623 кандидат педагогічних наук, доиент кафедри іноземних мов за фахом Національного авіаційного університету (Київ, Україна) 15natalybelous@gmail.com
\end{abstract}

\section{МОТИВАЦЙ̆НІ ПРОМОВИ БІЛА ГЕЙТСА ТА СТІВА ДЖОБСА: ЛІНГВО-ПРАГМАТИЧНА ХАРАКТЕРИСТИКА ТА СПОСОБИ ВІДТВОРЕННЯ УКРАЇНСЬКОЮ МОВОЮ}

\begin{abstract}
У статті охарактеризовано мотивачійний дискурс і коучинг як один із видів аргументативного дискурсу, визначено основні стилістично-прагматичні характеристики мотиваџійних промов Біла Гейтса та Стіва Джобса, розглянуто перекладацькі трансформації, застосовані у перекладі зазначених промов українською мовою.

У статті окреслено поняття мотиваційного дискурсу, зазначено основні різновиди коучингу. Виокремлено основні характеристики текстів мотиваційних промов: прагматичну орієнтацію на рецципієнта; інформативність; емочійно-образну спрямованість; включення особистого досвіду спікера; спрощене трактування наукових термінів і підходів. 3'ясовано та висвітлено роль мовної особистості мотиваційного спікера.

У проведеному дослідженні проаналізовано мотиваџійні промови відомих англомовних спікерів Біла Гейтса та Стіва Джобса. Виявлено їх лінгвістичні та прагматичні особливості.

Промови Біла Гейтса мають характерну структурну організацію, їм притаманні логіка та широке використання образних засобів викладення; звернення до власного досвіду; використання різногалузевої термінології для створення авторитету у реципієнтів, пряме спонукання до дії через використання речень наказового способу; залучення аудиторії до розмірковування разом за допомогою риторичних питань; створення довірливої атмосфери спілкування завдяки включенню елементів комічного.

Мотиваційні промови Стіва Дюобса вирізняються більш імпліцитною образністю, більшою залученістю персонального досвіду для встановлення глибшого контакту з аудиторією; широким застосуванням асоиіацій, антитез, відсутністю комічного та складної термінології з метою утримання уваги слухачів.

Окрім того, стаття розглядає перекладацькі трансформації, використані у перекладі виступів Біла Гейтса та Стіва Джобса украӥнською мовою для досягнення адекватного перекладу. Виявлено лексикосемантичні та лексико-граматичні трансформації зі значним домінуванням сукупності лексико-граматичних трансформацій.
\end{abstract}

Ключові слова: мотиваційний дискурс, коучинг, мотиваційна промова, перекладаццькі трансформації.

Kateryna PODSIEVAK, orcid.org/0000-0002-2114-4471 Candidate of Philological Sciences, Senior Lecturer at Korunets Department of English and German Philology and Translation Kyiv National Linguistic University (Kyiv, Ukraine) kateryna.podsievak@gmail.com 


Natalia BILOUS,
Associate Professor at the Department of Foreign Languages for Specialties
National Aviation University
Candidate of Pedagogical Sciences,
(Kyiv, Ukraine) 15natalybelous@gmail.com

\section{BILL GATES AND STEVE JOBS MOTIVATIONAL SPEECHES: LINGUISTIC AND PRAGMATIC SPECIFICS, MEANS OF TRANSLATING INTO UKRAINIAN}

The article describes the definition of motivation discourse and coaching as one of the types of argumentative discourse, defines key stylistic and pragmatic characteristics of Bill Gates's and Steve Jobs's motivational speeches as well as considers main translation transformations used in translating them into Ukrainian.

The article defines motivation discourse and main types of coaching. The main characteristics of motivation discourse texts are determined. They include recipient pragmatic addressing; informative orientation; emotional and figurative expressive means; speaker's personal experience inclusions; simplified terminology usage. The strong position of speaker's discourse personality is highlighted.

The research analyzes motivational speeches by Bill Gates and Steve Jobs. Their linguistic and pragmatic characteristics are revealed.

Bill Gates's speech is characterized by logical structure; direct addressing the audience; wide use of emotional expressive means and comic components to creat informal communication, personal experience and terminology to strengthen his expert position, imperative mood sentences to encourage and motivate the recipients.

Steve Jobs's motivational speech is distinguished by a higher degree of implicit expressiveness and wide use of associations used with the purpose to establish closer connection with the public. The research finds lack of comic components and terms, but direct addressing the audience and involvement of personal life experience to to hold the attention of the public.

The article also considers the translation transformations used in translating Bill Gate's and Steve Jobs's motivational speeches into Ukrainian. Both lexical and semantic, and lexical and grammatical transformations are identified. It is estimated that the group of lexical and grammatical translation transformations significantly prevail over other types of translation transformations.

Key words: motivation discourse, coaching, motivational speech, translation transformations.

Постановка проблеми. У сучасному світі 3 установкою на соціальний і фінансовий успіх дедалі більше людей дослухаються до бізнес-спікерів і коучів із особистого розвитку, щоб отримати необхідні мотивацію та поради для його досягнення. Серед численних ораторів лише ті, хто вміє вербально правильно побудувати свій виступ, здобувають особливу популярність, їхні промови перекладають для аудиторії інших країн. До таких спікерів належать Біл Гейтс і Стів Джобс, всесвітньо відомі своїми переконливими виступами.

Актуальність запропонованої статті зумовлюється інтересом до постатей Біла Гейтса та Стіва Джобса, котрі значно вплинули на розвиток сучасного суспільства, та характеристики вербальної організації їхніх публічних виступів, а також викликами, пов'язаними з відтворенням особливостей впливу мотиваційних промов на слухачів, що постають перед перекладачем.

Аналіз досліджень. Мотиваційний дискурс належить до аргументативного дискурсу, який розглядається вченими у різних аспектах. Так, Ю. В. Гілясев досліджує прагматичні особливості англомовного мотиваційного дискурсу (Гиля- сев, 2017), В. М. Юшак та I. М. Міщук вивчають лексико-стилістичні характеристики мовленнєвого впливу англомовних промов (Юшак, Міщук, 2020), В. Шарброу, С. Сімонс і Д. Кантріл - роль мотиваційних промов у бізнес-комунікації (Sharbrough et al, 2006). Соціально-психологічна сутність мотиваційного дискурсу розглянута у роботах В. А. Климчука (Климчук, 2015).

Промови Біла Гейтса, Марка Цукерберга та Стіва Джобса аналізують із погляду їх інтонаційної організації (Арнова, 2016) і мовної особистості спікера (Бережна, 2019). Незважаючи на значну кількість праць, присвячених дослідженню мотиваційного дискурсу, перекладацький аспект мотиваційних промов цих спікерів $\epsilon$ недостатньо вивченим.

Мета статті - виявити та проаналізувати лінгвістичні та прагматичні особливості англомовних промов Біла Гейтса і Стіва Джобса та способи їх відтворення українською мовою. Для досягнення мети дослідження поставлено такі завдання: визначити поняття мотиваційного дискурсу, проаналізувати лінгво-стилістичні та прагматичні особливості промов Біла Гейтса та Стіва Джобса, визначити основні перекладацькі трансформації, 
застосовані у перекладі зазначених промов українською мовою. Матеріалом дослідження слугували виступи Біла Гейтса та Стіва Джобса перед студентами, а також їх переклади українською мовою, доступні у мережі Інтернет.

Виклад основного матеріалу. Мотиваційний дискурс, або ж коучинг, відносять до різновидів аргументативного дискурсу. Розрізняють різні види коучингу: бізнес-коучинг, лайф-коучинг, спортивний, кар'єрний, адміністративний коучинг (Юшак, Міщук, 2021: 201). Відповідно, коучинг $є$ неоднорідним за своєю проблематикою та цільовою аудиторією.

Виступи мотиваційних лідерів відбуваються як у форматі великих зустрічей і зібрань, так i в режимі он-лайн семінарів і марафонів. Також популярними стають мотиваційні промови на он-лайн платформі TEDex i персональних YouTube каналах спікерів, що змушує їх більше уваги приділяти належній вербальній організації своїх виступів, оскільки такий формат зменшує можливість використання екстралінгвістичних факторів утримання уваги глядачів і слухачів. Окрім того, коучинг представлений мотиваційною літературою відповідного спрямування.

Однак, націлені на різних реципієнтів залежно від сфери застосування, усі види коучингу використовують ті самі лінгвістичні засоби для впливу на слухачів. Мотиваційний дискурс репрезентується у текстах промов і мотиваційної літератури, які характеризуються:

- прагматичною орієнтацією на реципієнта;

- інформативністю;

- емоційно-образною спрямованістю;

- включенням особистого досвіду спікера;

- спрощеним трактуванням наукових термінів і підходів (Гилясев, 2017: 68-71).

Особливу роль у мотиваційному дискурсі відіграє мовна особистість спікера. М. В. Бережна у своєму дослідженні на прикладі Стіва Джобса виокремлює такі риси сильного мотиваційного спікера:

- домінування інтуїції та логіки;

- концентрацію на картині загалом;

- усвідомлення важливості майбутнього;

- фігуральність та асоціативне мислення;

- багатий словниковий запас;

- прямоту та критичність мовлення (Бережна, 2019: 15).

Зазначені риси разом із навичками аналізу, узагальнення, критичного мислення, відповідальністю й ерудицією допомагають мотивувати слухачів / глядачів, змусити їх повірити отриманій інформації та діяти.
Розглянемо стилістично-прагматичні особливості окремих промов Біла Гейтса та Стіва Джобса.

Відома промова Біла Гейтса перед випускниками Гарварду у 2007 р. має такі ознаки мотиваційного дискурсу:

1) спрямована на реципієнтів: You graduates came to Harvard at a different time. You know more about the world's inequities than the classes that came before $<\ldots>$ In your years here I hope you've had a chance to think about how in this age of accelerating technology we can finally take on these inequities and we can solve them (1). Займенники уои та уоur вживаються для прямої спрямованості на адресата, що сприяє більш інтерактивному спілкуванню;

2) включенням особистого досвіду спікера: I left campus knowing little about the millions of young people cheated out of educational opportunities here in this country. And I knew nothing about the millions of people living in unspeakable poverty and disease in developing countries. It took me decades to find out (1). Вживання особистого займенника $I$ та згадування фактів власного життя створює більш неформальну ситуацію спілкування, що допомагає тримати реципієнтів залученими до слухання промови;

3) емоційність та образність - промова насичена тропами:

- епітетами (people living in unspeakable poverty; Harvard was a phenomenal experience for me. Academic life was fascinating (1). Епітети привертають увагу до найбільш вагомих моментів промови, викликаючи у слухачів глибокі емоції;

- риторичними питаннями (And you wanted to spend that time and money where it would have the greatest impact in saving and improving lives. Where would you spend it? For Melinda and I the challenge is the same. How can we do the most good for the greatest number with the resources we have? (1) Риторичні питання змушують шукати відповіді разом зі спікером і вірити його відповідям;

- гумором: I've been waiting more than 30 years to say this: "Dad, I always told you I'd come back and get my degree." I want to thank Harvard for this honor. I'll be changing my job next year and it will be nice to finally have a college degree on my resume (1). Комічний ефект фрагменту базується на загальновідомому факті з життя спікера, що він кинув Гарвардський університет і не отримав диплом, однак виступає перед його випускниками 30 років потому. Використаний на початку промови, гумор дозволяє зняти зайву напруженість $\mathrm{i}$ пафос, налаштувати контакт з аудиторією;

4) логічність: Pursuing that goal starts the 4-step cycle again. This is the pattern (1). Використання 
лексичних одиниць, які характеризують логічну послідовність викладення думки, має на меті змусити аудиторію стежити за думкою спікера;

5) використання термінів із різних галузей науки без пояснень у ненауковому контексті: $a$ vaccine that gives life-long immunity with a single dose (медицина), We can make market forces work better for the poor if we can develop a more creative capitalism. If we can stretch the reach of market forces so that more people can make a profit $<\ldots>$ press governments around the world to spend tax-payer money in ways that better reflect the values of the people who pay the taxes. If we can find approaches that meet the needs of the poor in ways that generate profits for business (економіка) (1). Такий підхід дає змогу спікеру апелювати як до власного статусу експерту в галузі, що має наслідком підвищення його авторитету, так і до загальних екстралінгвістичних знань реципієнтів, дозволяючи аудиторії наблизитися до лідера;

6) спонукання до дії: Don't let complexity stop you. Be activists. Take on big inequities (1). Використання наказового способу наприкінці промови безпосередньо мотивує до дії;

7) концентрація на майбутньому: The defining and ongoing innovations of this age, biotechnology, the personal computer and the internet give us a chance we've never had before $<\ldots>$ And I hope you will come back here to Harvard 30 years from now and reflect what you have done with your talent and your energy (1). Звертання до майбутнього у фінальній частині промови (лексичні одиниці із семантикою «нового, майбутнього» - innovation, this age, 30 years from now; граматичні засоби використання Future Simple Tense - will come back, протиставлення минулому - використання Present Perfect Tense - have never had before), 3 опорою на надію та віру (hope) надихає та мотивує на майбутні звершення.

Проаналізувавши зазначений фрагмент, ми побачили, що Біл Гейтс вміло тримає увагу публіки за допомогою правильної структурної організації, логіки й образності викладення; мотивує власним досвідом, авторитетом, прямим спонуканням до дії; залучає аудиторію до розмірковування разом; створює довірливу атмосферу спілкування та віри у слухачів.

Під час перекладу для досягнення адекватності й еквівалентності перекладачі змушені вдаватися до певних перетворень, що зумовлено різною граматичною будовою та семантикою англійської й української мов. Наприклад:

«But taking a serious look back I do have one big regret. I left Harvard with no real awareness of the awful inequities in the world, the appalling disparities of health and wealth and opportunity that condemned millions of people to lives of despair. I learned a lot here at Harvard about new ideas in economics and politics. I got great exposure to the advances being made in the sciences. But humanity's greatest advances are not in its discoveries but in how those discoveries are applied to reduce inequity» (1).

"Але якщо серйозно озирнутись (синтаксична заміна), я дуже жалкую про одне (вилучення, морфологічна заміна). Я кинув (диференціація) Гарвард (траслітерація) без справжнього розуміння жахливої нерівності у світі - шаленого диспаритету (калька) в охороні здоров'я (додавання), багатстві та можливостях, що прирікає (диференціація) мільйони людей на життя в розпачі. Я багато чому навчився в Гарварді про нові ідеї в економічі та політиці. Я глибоко познайомився (конкретизація) з досягненнями в науках (синтаксична заміна). Але найбільші досягнення людства (транспозиція) полягають не в його винаходах, а в тому, як иі винаходи застосовуються, щоб долати (диференціація, синтаксична заміна) нерівність» (2).

Найчастотнішим $є$ використання у перекладі випадків диференціації (модуляції), що дозволяє найточніше передати відтінки значень слів у контексті мотиваційної промови. Вилучення та додавання, а також інші лексико-граматичні трансформації застосовуються для компенсації втрат під час перекладу.

Стів Джобс також виступав перед випускниками університету. У 2005 р. він виступив перед випускниками Стенфордського університету. Проаналізуємо фрагмент його промови:

1) спрямованість на реципієнтів: I am to be with you today at your commencement from one of the finest universities in the world (3). Займенники другої особи уои та уоur вказують на пряме звертання до аудиторії. Стів Джобс починає промову доволі офіційно, про що свідчить лексика офіційного стилю (I am honored, commencement, one of the finest universities in the world). Таким чином спікер звертає увагу слухачів на важливість моменту події - отримання диплома про вищу освіту - у їхньому житті;

2) включенням особистого досвіду спікера: Today I want to tell you three stories from my life. $<\ldots>$ I had no idea what I wanted to do with my life. $<\ldots>$ I had been rejected, but I was still in love. $<\ldots>$ I had the surgery and I'm fine now (3). Вживання займенників першої особи I та $m y$, три дуже особисті історії власного життя створює більш неформальну ситуацію спілкування, що допома- 
Перекладацькі трансформації у перекладі промов Біла Гейтса

\begin{tabular}{|l|l|c|}
\hline \multicolumn{1}{|c|}{ Тип трансформації } & \multicolumn{1}{|c|}{ Вид трансформації } & \% \\
\hline Транскодування & Транслітерація & $5 \%$ \\
& Калька & $29 \%$ \\
\hline Лексико-семантичні & Диференціація & $6 \%$ \\
\hline Лексико-граматичні & Конкретизація & $6,5 \%$ \\
& Вилучення & $7,5 \%$ \\
& Додавання & $12,5 \%$ \\
& Морфологічна заміна & $12 \%$ \\
& Синтаксична заміна & $7,5 \%$ \\
& Транспозиція & $10 \%$ \\
\hline
\end{tabular}

гає тримати реципієнтів залученими до слухання промови, включає емоційну зацікавленість розповіддю;

3) образність та асоціативне мислення: The first story is about connecting the dots (3). Стів Джобс розповів про своє народження, прийомних батьків, які були простими робітниками, та про те, як покинув університет і через бідність міг відвідувати лише курси каліграфії, з'єднуючи точки та перетворюючи їх на ідеальне письмо. За словами спікера, ці навички здавалися йому непрактичними, доки не настав час створювати шрифти для «Макінтош». Ідіоматичний вираз connecting the dots має значення «зводити кінці з кінцями», тобто перебувати у складному становищі, бути бідним. Стів Джобс використав асоціацію буквального значення виразу із ситуацією навчання каліграфії, а асоціацію метафоричного значення виразу iз життєвою ситуацією опанування навичок у складній ситуації, які з часом можуть виявитися дуже корисними;

4) емоційніть мовлення: It clears out the old to make way for the new. $<\ldots>$ I didn't see it then, but it turned out that getting fired from Apple was the best thing that could have ever happened to me. The heaviness of being successful was replaced by the lightness of being a beginner again (3). У промовах Стіва Джобса нечисленні епітети, однак спікер також широко використовує антитези (clear out-make; heaviness - lightness; getting fired - the best thing (контекстуальна антитеза) для надання більшої емоційності та, як результат, більшого ступеня концентрації уваги слухачів;

5) прямота та логічність мовлення: During the next five years, I started a company named NeXT, another company named Pixar $<\ldots>$ Pixar went on to create the world's first computer animated feature film, Toy Story, and is now the most successful animation studio in the world. In a remarkable turn of events, Apple bought NeXT, I returned to Apple (3). Використовуючи асиндетичні зв'язки між частинами складносурядних речень, спікер логічно викладає події свого життя, без зайвих слів описуючи їх, що створює ефект швидкого плину часу, коли одне швидко та логічно випливає з іншого, та змушує аудиторію швидко стежити за думкою мовця;

6) спонукання до діï: Your time is limited, so don't waste it living someone else's life. Don't be trapped by dogma - which is living with the results of other people's thinking. Don't let the noise of others' opinions drown out your own inner voice. And most important, have the courage to follow your heart and intuition (3). Використання наказового способу наприкінці промови безпосередньо мотивує до діï, як і у промовах Біла Гейтса.

3 наведеного аналізу робимо висновок, що промови Стіва Джобса стриманіші, однак більш насичені особистими алюзіями та персональними історіями, що змушує аудиторію уважно слухати та стежити за його логікою й асоціативним мисленням. Слухачі наче проживають із ним його життя і роблять ті самі висновки, що i спікер. Використовуючи наказовий спосіб у фінальній частині промови, Стів Джобс закликає та надихає.

Для розкриття імпліцитного змісту тексту промов Стіва Джобса під час перекладу українською мовою доводиться використовувати більше перекладацьких трансформацій. Це зумовлено необхідністю передати у тесті мовою перекладу той мовленнєвий вплив, який має тест вихідною мовою. Наприклад:

"I'm pretty sure none of this would have happened if I hadn't been fired from Apple. It was awful tasting medicine, but I guess the patient needed it. Sometimes life hits you in the head with a brick. Don't lose faith. I'm convinced that the only thing that kept me going was that I loved 
what I did. You've got to find what you love. And that is as true for your work as it is for your lovers. Your work is going to fill a large part of your life, and the only way to be truly satisfied is to do what you believe is great work. And the only way to do great work is to love what you do. If you haven't found it yet, keep looking. Don't settle. As with all matters of the heart, you'll know when you find it. And, like any great relationship, it just gets better and better as the years roll on. So keep looking until you find it. Don't settle» (3).

Я впевнений, щз нічого з иьвого не трапилося б, якби мене не звільнили з Apple (нульове транскодування). Ліки були гіркими (конкретизація), але паціснтові вони допомогли (диференціація) - переклад за допомогою аналогії. Іноді життя б'є вас по голові иеглиною. Переклад за допомогою калькування. Не втрачайте віри. Я переконаний, що єдина річ, щзо допомогла мені продовжувати, було те, що я любив свою справу (морфологічна заміна, описовий переклад). Вам треба знайти те, що ви любите. I ие так само правильно для роботи, як $і$ для стосунків (генералізація). Ваша робота заповнить велику частину життя, $і$ єдиний спосіб бути цілком задоволеним - робити те, щяо, на вашу думку, є великою справою. I єдиний спосіб робити велику справу - любите те, щзо ви робите. Якщзо ви ще не знайшли своєї справи (додавання)- шукайте. Не зупиняйтеся (диференціація). Як ие буває в коханні (конкретизація), ви довідаєтеся тоді, коли знайдете. I, як будь-які гарні (диференціація) стосунки, вони стають лише кращими з роками (синтаксична заміна). Тому шукайте - поки не знайдете (вилучення). Не зупиняйтеся (диференціація)» (4).

Найчастотнішими перекладацькими трансформаціями є диференціація (модуляція), додавання та синтаксична заміна, що дозволяють найточніше передати відтінки значень слів у контексті мотиваційної промови. Загальна частка лексико-граматичних трансформацій становить 56,25\%, що свідчить про необхідність застосування широкого спектра перекладацьких перетворень для компенсації можливих втрат у перекладі та найповнішої передачі більш імпліцитного характеру мотиваційних промов Стіва Джобса.

Висновки. Дослідження мотиваційних промови Біла Гейтса та Стіва Джобса виявило наявність стилістично-прагматичних засобів конструювання промов для досягнення впливу на реципієнтів. Серед них можна виокремити вживання займенників першої та другої особи, форми майбутнього часу, наказовий спосіб у спонукальних реченнях і використання термінів (лексичні засоби), епітети, метафори, антитези й елементи комічного (стилістичні засоби), а також риторичні питання, асиндетон (синтаксичні засоби), кожен із яких вживається 3 певною прагматичною метою. Серед способів відтворення мотиваційних промов Біла Гейтса та Стіва Джобса українською переважають лексико-граматичні трансформації, найчастотнішою 3 яких є диференціація. Вбачаємо перспективу досліджень у подальшому порівняльному аналізі мотиваційних промов різних коучів i більш детальному квалітативному аналізу їх україномовного перекладу.

Таблиця 2

Перекладацькі трансформації у перекладі промов Стіва Джобса

\begin{tabular}{|l|l|c|}
\hline \multicolumn{1}{|c|}{ Тип трансформації } & \multicolumn{1}{|c|}{ Вид трансформації } & \multicolumn{1}{c|}{$10 \%$} \\
\hline Транскодування & Нульове транскодування & $4 \%$ \\
& Транслітерація & $2 \%$ \\
\hline Лексико-семантичні & Калька & $16,5 \%$ \\
& Диференціація & $6,25 \%$ \\
& Конкретизація & $5 \%$ \\
\hline Лексико-граматичні & Генералізація & $8 \%$ \\
& Вилучення & $10,25 \%$ \\
& Додавання & $4 \%$ \\
& Морфологічна заміна & $10 \%$ \\
& Синтаксична заміна & $6 \%$ \\
& Транспозиція & $2 \%$ \\
& Антонімічний переклад & $8 \%$ \\
& Описовий переклад & $2 \%$ \\
\hline
\end{tabular}




\section{СПИСОК ВИКОРИСТАНИХ ДЖЕРЕЛ}

1. Арнова Н. В. Анализ и интерпретация интонационных параметров речи ораторов в презентации нового продукта (на материале устных презентаций американских предпринимателей Стива Джобса, Билла Гейтса и Марка Цукерберга). Вестник Костромского государственного университета. № 3. 2016. С. 186-191.

2. Бережна М. В. Стів Джобс як метасимволічна сильна мовна особистість. «Філологічні трактати». Т. 11 . № 1. 2019. C. $15-24$.

3. Гилясев Ю. В. Прагматика англоязычного мотивационного дискурса. Ученые записки Петрозаводского государственного университета. 2017. № 5 (166). С. 70-76.

4. Климчук В. А. Мотивационный дискурс личности: количественные характеристики и сравнительный анализ. Социальная психология и общество. Т. 6. № 1. 2015. С. 68-81.

5. Крутько Т. В. Стратегії мовленнєвого впливу у промовах бізнес-коучів (на матеріалі персональних сторінок соціальної мережі Facebook). Лінгвістика XXI століття: нові дослідження і перспективи : збірник наукових праць НАН України. Київ : Центр наукових досліджень і викладання іноземних мов, 2017. С. 106-112.

6. Науменко Л. П. Функціонально-прагматична характеристика англомовного бізнес-дискурсу в інтернет-просторі. Теоретична і дидактична філологія: Сер. «Філологія. Педагогіка». 2017. Вип. 25. С. 290-299.

7. Юшак В. М., Міщук І. М. Засоби мовленнєвого впливу в англомовних мотиваційних промовах Ніка Вуйчича. Науковий вісник ДДПУ імені І. Франка. Серія: Філологічні науки (мовознавство). № 13. 2020. С. $200-204$.

8. Crystal D. Language and the Internet. Cambridge University Press, 2001. 272 p.

9. Sullivan J. Three roles of language in motivation theory. Academy of Management Review. V. 13. № 1. 1988. P. $104-115$.

10. Sharbrough W., Simmons S., Cantrill D. Motivating language in industry. Its impact on job satisfaction and perceived supervisor effectiveness. Journal of Business Communication. V. 43. № 4. 2006. P. 322-343.

\section{ДЖЕРЕЛА ІЛЮСТРАТИВНОГО МАТЕРІАЛУ}

1. https://singjupost.com/bill-gates-commencement-speech-at-harvard-2007-full-transcript/?singlepage=1.

2. http://iee.org.ua/ru/prog_info/21884/.

3. https://news.stanford.edu/2005/06/14/jobs-061505/.

4. http://poklykannja.com.ua/Stiv_Jobs/.

\section{REFERENCES}

1. Arnova A. V. (2016). Analiz i interpretatsiya intonatsionnyh parametrov rechi oratorov v prezentatsii novogo produkta (na materiale ustnyh prezentatsiy amerikanskih predrinimateley Stiva Djobsa, Billa Geytsa i Marka Tsukerberga). [ Analysis and Interpretation of Speakers' Speech Parameters at New Products Presentation (based on oral presentations of American entrepreneurs Steve Jobs, Bill Gates and Mark Zukerberg)]. Izvestiya Kostromskogo gosudagrstvennogo universiteta. 3, 186-191 [in Russian].

2. Berezhna M. V. (2019) Stiv Djobs iak metasymvolichna sylna movna osobystist [Steve Jobs as Strong Metasymbolic Language Personality]. Filologichni traktaty. 11 (1), 15-24 [in Ukrainian].

3. Gilyasev, Yu. V. (2017). Pragmatika angloyazychnogo motivatsionnogo diskursa [The Pragmatics of the English Motivational Discourse]. Uchenye zapiski Petrozavodskogo gosudarstvennogo universiteta. 5 (166), $70-76$ [in Russian].

4. Klimchuk V. A. (2015). Motivatsionniy discurs lichnosti: kolichestvennyye kharakteristiki i sravnitelnyy analiz [Motivation Discourse of Personalilty: Qualitative Characteristics and Comparative Analysis]. Sotsialnaya psikhologiya i obshchestvo. 6 (1), 68-81 [in Russian].

5. Krutko, T. V. (2017). Strategiyi movlennyevogo vplyvu u promovax biznes-kouchiv [Communication Strategies Employed by Business Coaches]. Lingvistyka XXI stolittya: novi doslidzhennya i perspektyvy, 106-112 [in Ukrainian].

6. Naumenko, L. P. (2017). Funktsionalno-pragmatychna harakterystyka anglomovnogo biznes-dyskursu v internet-prostori [Functional and Pragmatic Characteristics of the English Business Discourse in the Internet]. Teoretychna i dydaktychna filologiya: Seriya "Filologiya. Pedagogika", 25, 290-299 [in Ukrainian].

7. Yushchak V. M., Ishchuk I. M. (2020). Zasoby movlennievogo vplyvu v anglomovnyh motyvatsiynyh promovah Nika Vuychicha [Linguistic Means of Expressing Persuasive Impact in Nick Vujicic's Motivational Speeches]. Naukovyi visnyk DDPU imeni I. Franka. Seriia: "Filologichni nauky (movoznavstvo)". 13, 200-204 [in Ukrainian]. 